\title{
Adrienn NAGY* \\ Changes in judicial practice related to the land transaction act after reforms of procedural acts**
}

\section{Introduction}

The so-called 'moratorium on purchases of agricultural land', i.e. ban of foreign ownership of agricultural land, of Hungary expired within the European Union on 30 April 2014. At the same time, agricultural land is a source of power with strategic importance that, based on its legal protection, gave grounds for the making of such an implementing act, which provides who and under what circumstances may acquire agricultural land. As a result of that, Act CXXII of 2013 on Transactions in Agricultural and Forestry Land (hereinafter: Land Transaction Act) was passed.

Since its entry into force, the Land Transaction Act has been modified and specified many times and the connecting judicial practice is far-reaching as well. Therefore, the aim of this paper is, first of all, to clarify the due course of procedures in the case of transactions of agricultural land ownership, ${ }^{1}$ with special regard to procedural reforms, i.e. the entry into force of the Act CXXX of 2016 on the Code of Civil Procedure (hereinafter: Code of Civil Procedure) and of the Act I of 2017 on the Code of Administrative Court Proceeding (hereinafter: Code of Administrative Court Proceeding), which entered into force on 1 January 2018. Basically, this paper seeks to find out what kind of essential changes may take place in civil enforcement before courts and whether the enforcement of rights for contracting parties will be harder or easier.

\section{Raising of the problem}

Under the scope of the Land Transaction Act, both a procedure fallen within the competence of the notary and an administrative proceeding within the competence of the agricultural administration body precede the real estate registration procedure in the case of transaction of agricultural land ownership by sales contract so as to pursue

Adrienn Nagy: Changes in judicial practice related to the land transaction act after reforms of procedural acts - Változások a földforgalmi törvényhez kapcsolódó bírósági joggyakorlatban az elárásjogi törvények reformja után. Journal of Agricultural and Environmental Law ISSN 1788-6171, 2018 Vol. XIII No. 25 pp. 132-156 doi: 10.21029/JAEL.2018.25.132

* dr. jur., PhD Head of Institute of European and International Law, School of Law, University of Miskolc, e-mail: jogadri@uni-miskolc.hu

** This study has been written as part of the Ministry of Justice programme aiming to raise the standard of law education.

1 The raising of the problem originates from Olajos István: Mezőgazdasági földterületek tulajdonszerzése és hasznosítása, különös tekintettel a formálódó magyar bírósági gyakorlatra, Agrár-és Környezetjog, 2017/23, 105, doi: 10.21029/JAEL.2017.23.91. 
the right of preemption. The purposes of the right of preemption are the examination of the buyer's ability to obtain and the appointment of the proper buyer among more buyers entitled to the right of preemption under the Land Transaction Act. Sales contracts shall be recorded in a document bearing the safety features provided for in the decree adopted for the implementation of this Act, which shall be provided with an approving clause (with decision) by the agricultural administrative body. After that, during the real estate registration procedure, only the existence of aspects provided in Act CXLI of 1997 on Real Estate Registration needs to be examined. ${ }^{2}$

If an agricultural administrative body refuses to approve a sales contract within the administrative procedure under Section 23 of the Land Transaction Act, an appeal shall not lie within that administrative procedure and only judicial review may be requested, i.e. administrative court proceeding may be initiated. ${ }^{3}$ However, the possibility of initiation of an administrative court proceeding shall not exclude the initiation of a proceeding to declare the contract null and void by the court in accordance with the Act V of 2013 on the Civil Code (hereinafter: Civil Code) related to sales contracts.

The possibility of simultaneous initiation of an administrative court proceeding and a civil proceeding by itself would not raise any problem, since the purposes of these two procedures are different: while the object of an administrative court proceeding is to clarify the legality of an administrative activity in accordance with the rules of the Code of Administrative Court Proceeding, a civil proceeding basically aims the judgment of the validity of a contract under the rules of the Code of Civil Procedure. The problem derives from Section 23 (1) a) of the Land Transaction Act, under which the agricultural administrative body shall take it also into consideration when examining sales contracts related to agricultural lands during an administrative procedure, whether the sales contract shall be qualified as an agreement non-existent due to breaches of statutory requirements or an agreement null and void, and in so far as it may be established, the agricultural administrative body shall refuse the approval. Notwithstanding, it may occur during an administrative court proceeding initiated after an administrative proceeding that the plaintiff requests the court, referring to Section 23 (1) a) of the Land Transaction Act, to establish the unlawfulness of the administrative decision and refers to the provisions of the Civil Code related to invalidity at the same time. ${ }^{4}$ In this case, is avoiding of a sales contract referring to that contract qualifies as an agreement non-existent or an agreement null and void excluded?

From perspectives of procedural law answering this question may be attempted by analysing two legal institutions: the substantive force and the principle of free deliberation of relevant facts of a case.

\footnotetext{
2 Olajos 2015, 105.

${ }^{3}$ Section 30 (5) of Land Transaction Act.

${ }^{4}$ See e.g. Judgment of Curia 'Kpf.' No.III.37.681/2016.
} 


\section{Procedural law reforms: Changes in the review of unlawful administrative activities}

Before answering the emerging question, it is inevitable to say a few words about those procedural reforms which have brought about significant changes in the lives of the parties to the proceedings since 1 January 2018. Previously, administrative court proceeding used to be regulated by the Act III of 1952 on the Code of Civil Procedure (hereinafter: Code of Civil Procedure of 1952), while proceedings to declare a contract null and void by the court, used to be conducted under the General Provisions of the Code of Civil Procedure of 1952. Whilst, since 1 January 2018, administrative court proceedings have been regulated under the Code of Administrative Court Proceeding, civil proceedings have been regulated in accordance with the Code of Civil Procedure of 2016. These procedural acts regulate legal proceedings based on different approaches, which are going to be elaborated in further chapters of this paper.

After the Code of Administrative Court Proceeding having come into force, changes have also ensued in initiating and conducting of administrative court proceedings, as well as in appeals against sentences passed in administrative court proceedings in connection with the Land Transaction Act.

Under Section 30 (5) of the Land Transaction Act, no appeal may lie against the decision of an agricultural administrative body within an administrative proceeding, so the only option for a remedy is to initiate an administrative court proceeding.

If an administrative court proceeding was initiated, a correction of infringement shall take place, first of all, within the own system of public administration: If an administrative body establishes, based on a claim, ${ }^{5}$ that its decision shall breach a statutory provision, it shall modify or withdraw that decision; if it agrees with the content of a claim and there is no counterparty in the case, the administrative body may withdraw its decision even if it is not unlawful and may also modify it in accordance with the content of the statement of claim. ${ }^{6}$

In so far as an injurious decision was not withdrawn or modified by an administrative body within its own competence, then an administrative court proceeding shall be settled by a court proceeding in the administrative case; in that case, a claim shall be forwarded to an administrative and labour court having competence and jurisdiction in that case. Section 12 of the Code of Administrative Court Proceeding provides that a court with general competence shall mean an administrative and labour court, whereas under Section 13 of the Code of Administrative Court Proceeding, the location of a real estate shall be determining from a jurisdictional the point of view, on one condition, that is, under the provisions of the Code of

\footnotetext{
5 According to Section 39 (1) of Code of Administrative Procedure Code by initiating an administrative action plaintiff shall submit his action at the administrative authority, there was no change has taken place in this sence.

${ }^{6}$ Pribula László: Közigazgatási perek, in: Nagy Adrienn - Wopera Zsuzsa (edit.): Polgári eljárásjog II., Budapest, Wolters Kluwer Kiadó, 2018, in press.
} 
Administrative Court Proceeding, only the eight administrative and labour courts shall proceed in these cases with regional jurisdiction. ${ }^{7}$

Entry into force of the Code of Administrative Court Proceeding did not bring about essential changes in permission of appeals against first instance sentences delivered in administrative court proceedings.

Section 340 (1) of the Code of Civil Procedure of 1952 used to exclude the right to appeal in general against sentences delivered in administrative court proceedings. An appeal against the decision of a court may have only lain, if two conditions provided in Section 340 (2) of the Code of Civil Procedure of 1952 had jointly been carried out, namely: (a) the administrative court proceeding was initiated for judicial review of such a first instance administrative decision, against which no appeal may lie, and (b) the court may modify the administrative decision authorised by law.

Under the Land Transaction Act, an appeal against a first instance sentence of a court used to be also allowed by the provisions of the Code of Civil Procedure of 1952 during a judicial review of a decision of an agricultural administrative body, since the Land Transaction Act excluded the right to appeal in an administrative proceeding and Section 39 of the Act CCXII of 2013 on certain provisions and provisional regulations provided reformative sphere of body for the court related to Act CXXII of 2013 on Transactions in Agricultural and Forestry Land.

Section 99 (1) of the Code of Administrative Court Proceeding has reserved, as a general rule, the exclusion of an appeal against a sentence delivered in an administrative court proceeding, therefore an appeal against the sentence of the court may only lie, if the Code of Administrative Court Proceeding or other act shall make it possible.

Act L of 2017 on Modifications of Certain Acts Related to the Entry into Force of the Act on General Public Administration Procedures and of the Code of Administrative Court Proceeding (a 'mixture' act) has modified Section 39 of the Act CCXII of 2013 according as that an appeal against a first instance sentence of a court may lie, except a first instance sentence delivered in an administrative court proceeding initiated against a statutory certificate of an agricultural administrative body, which may be exclusively settled by the 'Fővárosi Törvényszék', i.e. the capital court in Budapest, the only court having jurisdiction under Section 13 (11) of the Code of Administrative Court Proceeding.

A real change was brought about by the entry into force of the Code of Administrative Court Proceeding in connection with the admissibility of judicial reviews, as in accordance with Section 340/A (1) of the Code of Civil Procedure of 1952 a judicial review used to be admissible against a sentence entered into effect on a first instance. With regard to the above mentioned provision, judicial review used to

\footnotetext{
${ }^{7}$ In administrative court procedures in most of the cases eigth priority status administrative and labour court shall be hold trials as court of first instance, each court has the jurisdiction of 1 to 3 counties. These priority status administrative and labour courts are the following: Fóvárosi, Budapest Környéki, Debreceni, Győri, Miskolci, Pécsi, Szegedi, Veszprémi Közigazgatási és Munkaügyi Bíróság.
} 
'take over' the function of a general remedy in many cases, and with also regard to that a statutory breach had to be referred in a claim and indication of a statutory breach used to be a mandatory element of a judicial review request as well.

Nonetheless, under Section 118 of the Code of Administrative Court Proceeding, proposal for a judicial review against a sentence delivered in an administrative court proceeding is subject to grave conditions, since in a judicial review request, besides the indication of a statutory breach affecting the merit of a case, even one of the following aspects shall be referred: analysis of a statutory breach affecting the merit of a case is justified due to (a) providing consistency or development of the case-law, (b) special significance and social importance of the raised question of law, respectively, (c) necessity of a preliminary ruling before the Court of Justice of the European Union, or (d) provision of a sentence deviating from the disclosed case-law of the Curia.

After having submitted a judicial review request, a three-member chamber of the Curia shall examine, outside of negotiation within 30 days, first of all, whether that judicial review request shall meet the requirements, i.e. it shall deicide upon the admissibility of that judicial review request. This aggravation of law will have considerable impact on the case-law related to the Land Transaction Act, as it is exceptional that a case reaches the Curia so that the Curia takes that into account substantively. All these also result that administrative and labour courts proceeding on a first instance and the 'Fôvárosi Törvényszék' proceeding on a second instance shall have greater responsibility in making the right decision.

\section{Answering the question by the examination of substantive force}

We may solve the problem pointed out in the second point of this article through the interpretation of the institution of substantive force. The main issue is to answer the question whether the substantive force of judgement made by the administrative court excludes or restricts plaintiff's right to initiate a civil proceeding in the question of invalidity of contract or not.

The definition of substantive force is defined by both the Code of Administrative Court Procedure and the Code of Civil Procedure. According to Section 96 of Code of Administrative Court Proceeding: The substantive force of judgement brought in the question of legality of an administrative activity precludes to have another action brought by the same parties or interested persons for the legality of the same administrative activity, or to dispute the judgment in any other way. So the Code of Administrative Court Proceeding constitutes this definition in connection with administrative court proceedings and to the determination of substantive force the identity of parties and administrative activity subject to the case is necessary.

Section 360 (1) of the Code of Civil Procedure defines substantive force as: Substantive force of a final judgment rendered in connection with a right enforced by a claim or by way of offsetting adjudicated in substance having regard to a counterclaim precludes to have another action brought by the same parties against one another - including their successors as well - for the same right under the same factual grounds, and it constitutes an absolute bar for such parties to dispute a 
substantive judgment already adopted in the case. In civil cases, substantive force has basically three conditions: identity of parties, of facts and of law.

Basically, we may point out by answering the problematic question of this article whether identity of law could be established in judgments brought in administrative and civil litigation or not. To solve this issue, we have to start with the interpretation of content of the claim, in connection with there were fundamental changes during procedural reforms.

Section 121 (1) of the Code of Civil Procedure of 1952 - according to its' last effective condition ${ }^{8}$ - concludes the mandatory elements of the claim only in five points. Under Section 121 (2) c) of the Code of Civil Procedure of 1952 a claim shall indicate the cause of action, including a description of the circumstances invoked as the basis of the claim and a description of the evidence supporting the claim. This legal provision was developed the dilemma of compulsory legal title or pleading of the claim in court practice and legal literature. ${ }^{9}$ According to the legal practice upon the Code of Civil Procedure of 1952 for the determination of cause of an action plaintiff is not necessary to refer to a concrete statutory provision. Plaintiff let the court know what is the right sought to be awarded, on the basis of which he submitted a claim against the other party, and it has a direction towards the court's decision. Plaintiff shall indicate the cause of action with a description of the circumstances invoked as the basis of the claim and a description of the evidence supporting the claim, i.e. he shall present all the legally relevant facts in the particular case in a chronological order, which he proves through the means of evidence offered by him. It is important to indicate fact in an accurate and detailed manner since the judgment of the court shall be based upon the statements of the parties to the litigation only, in fact, the Code of Civil Procedure of 1952 increasingly strengthening the judicial practice that a court shall base its judgement on the facts presented by the plaintiff (and the defendant), and it may differ from legal basis presented by the plaintiff whether it may be inferred from the presented facts. ${ }^{10}$ It is also means whether the plaintiff would state an incorrect legal title, it may not result in refusal in the case if there were available all the fact, evidences, data to determine the correct legal title and legal assessment. ${ }^{11}$ Upon the Code of Civil Procedure of 1952 there were two main pillars of adjudication of civil cases: statement of facts and pleading. This interpretation was confirmed by provision of Section 212 of the Code of Civil Procedure of 1952 that only requests made by the parties shall be binding upon the court.

\footnotetext{
8 The Act CXXX of 2005 extended the mandatory elements of claim with a sixth element, upon the plaintiff has to mention in his claim if there was a mediation procedure between the parties, except those cases where mediation is prohibited. This provision was in force till 31 December 2008, and Repealed under the Act of XXX 2008, effective as of 1 January 2009.

${ }^{9}$ See Pákozdi Zita: A jogerö tárgyi terjedelme a polgári perben, PhD Thesis, Szeged, 2015.

${ }_{10}$ Andrea Nagy: Eljárás az elsőfokú bíróság előtt, in: Wopera Zsuzsa (edit.): Polgári perjog általános réš, Budapest, CompLex Kiadó, 2008, 301.

${ }^{11} \mathrm{EBH} 2004.1143$.
} 
The rules of Code of Civil Procedure, entered into force on 1 January 2018, have brought significant tightening: Section 170 of the Civil Procedure Code gives a more detailed list of mandatory elements of statement of claim. The new regulation, putting more emphasize on party autonomy, changes the requirements of the Code of Civil Procedure of 1952, and as a new element, requires the nomination of the right sought to be awarded and submitting legal argument. So adjudication of the case is now based on three pillars: statement of facts - pleading - plaintiff's statement of right. Legal argument showing causal relationship between the right sought to be awarded, the factual claims and the claim shall be deducted by the plaintiff. ${ }^{12}$

This tightening could be explained by counting general courts as generally competent courts upon the rules of procedure of first instance of the Code of Civil Procedure, where legal representation is mandatory for all the parties during the procedure of first and second instance and during extraordinary remedy. If the claim was made by a representative having passed the professional law examination, it is highly desirable for him to be given a precise indication of statement of right. The requirement of stating right sought to be awarded is also important, because it is in correlation with lis pendens and substantive force. ${ }^{13}$

In favour of predictability of judgements and fairness of procedures Section 170 of Civil Procedure Code made it compulsory to name the right sought to be awarded in the claim. So the court shall not establish the right sought to be awarded upon the presented facts in the future. According to the Section 342 (3) of Civil Procedure Code court is bound by the right stated by the parties, i.e. statement of rights while making its decision has binding force. The potential tension between binding force of legal statements and finding substantive justice is significantly softened by the new legal institution of substantive conduct of the proceedings. ${ }^{14}$

Section 7 of the Code of Civil Procedure declares within the interpretative provisions the two most important definitions in connection with statement of rights: the right asserted by action and the legal basis. Plaintiff could make his statement of rights basically in two way: giving the concrete statutory provision [e.g. Section 6:535 (1) of Civil Code] on one hand, and acknowledging the content of legal provision underlying that right (e.g. compensation of damages resulting from liability for hazardous operations) on the other. ${ }^{15}$ The indication of invalidity of the contested contract in itself does not fulfil the statutory requirements.

The strict rules of Civil Procedure Code were shaded by the provision according to in actions falling within the competence of district courts as court of first instance, legal representation is not compulsory. If the plaintiff in this case he submits his claim without legal counsel, under the subsection (1) of Section 246 of Civil

${ }^{12}$ Cf. Wopera Zsuzsa: Az új polgári perrendtartás karakterét adó egyes megoldások európai összehasonlításban, ADVOCAT, 2017/special edition, 6.

${ }^{13}$ Wallacher Lajos: Perindítás, in: Wopera Zsuzsa (edit.): Kommentár a polgári perrendtartásról szóló 2016. évi CXXX. törvényher, Budapest, Magyar Közlöny Lap- és Könyvkiadó Kft., 2017, 351.

14 Zsitva Ágnes: Perindítás, in: Wopera Zsuzsa (edit.): A polgári perrendtartásról sqóló 2016. évi CXXX. törvény magyarázata, Budapest, Wolters Kluwer Kiadó, 2017, 255-256.

15 Zsitva 2017, 256. 
Procedure Code he shall submit it by using a standard printed form according to the 21/2017. (XII.22.) Ministerial decree of Ministry of Justice, with the derogation of Section 247 of the Civil Procedure Code that the party is not obliged to indicate in his claim the legal basis, the legal argument and the specific statutory provision. However, abandoning legal basis does not mean that parties do not have to take legal statement. It just means, in the absence of legal representation, parties do not have to take a professional legal statement. In the case of legal statement of party without legal counsel the difference is that he could also express the right asserted by action by other appropriate means if the legal basis could be identified from it. But this is not the same as the approach and maintaining practice regulated in the Section 121 (1) c) of Code of civil Procedure of $1952 .{ }^{16}$ This is why it is practical to take the advantages of opportunity laid down in Section 246 (2), namely the oral presentation of claim on a grievance day, where the court fulfils the standard printed form applied by the Ministry of Justice. ${ }^{17}$

In civil cases invalidity of contracts is a special field of the right asserted by action and related questions. Special in the manner, that principle of officiality, which is far from civil litigation, got an important role, and on the other hand after a while, it also appeared, in certain sense, that the right asserted is binding upon the court. ${ }^{18}$

We can differ two main categories of grounds for invalidity: grounds for nullity and avoidance. Nullity is the stronger case, no special procedure is required for the establishment of nullity, and the court shall observe the grounds for it in its own motion. ${ }^{19}$ On the contrary, in cases of avoidance the aggrieved party and persons with a lawful interest in the avoidance of a contract shall be entitled to avoid it, about the ground for avoidance shall be sent a notice to the other party within a period of one year, and if it was unsuccessful, he shall bring a claim to the court, and the court does not have to observe grounds for avoidance of its own motion.

In the point of penalties and legal consequences of grounds for invalidity, however, there is no difference: an invalid contract cannot have legal effect, the legal consequence could be declaration of contract in question valid, restitution, and payment for monetary value for unjust enrichment. ${ }^{20}$

At the time, by adoption of the old Civil Code (Act of IV of 1959) in cases of invalidity overall officiality was prevailed, and this was also the case by applying legal consequences of invalidity. In the stand of Supreme Court no. 32 PK in the question of legal consequences Supreme Court preferred restitution. Upon no. 32 PK statement court not only shall take into account grounds for invalidity ex officio, but it also shall declare the legal consequences ex officio.

\footnotetext{
16 Zsitva $2017,362$.

${ }^{17}$ It is important to emhasize if the plaintiff is represented by legal counsel in an action within district court competence, he is not subject to this derogation, so statement of claim have to fulfil the requirements set out in Section 170 of Code of Civil Procedure.

18 Pákozdi 2015, 73.

${ }_{19}$ Ptk. 6:88. \(1).

20 Pákozdi 2015, 74.
} 
The 1/2005. (VI.15.) PK opinion has changed the aforementioned legal practice and stated that court shall apply the legal consequence of invalidity only in case of request was made, never ex officio, not even initiating the ground for nullity. Since the official initiation of court shall not be meant an obligation to the judge he should look for any possible causes of nullity, but it cannot mean either to invoke parties in order to clarify the cause of nullity.

The first point of no. 1/2010. (VI.28.) PK opinion declared outdated no. 32 PK statement, and the Civil Collage of Supreme Court issued a new guideline. In this context, the Supreme Court issued no. 2/2010. (VI.28.) PK opinion on certain procedural issues of invalidity cases, from which we have to point out the followings.

A party shall exactly indicate which legal consequence of invalidity and what kind of content he would like to be applied by the court in his claim for condemnation.

A court shall perceive ex officio only that case of nullity, which is as a fact clearly established and obvious on the basis of the evidence available. A court shall not conduct a procedure to taking an evidence to establish nullity on its own motion. A court also shall perceive officially the case a contract does not exist.

Unless otherwise provided for by an act, the statement of facts and subject of the claim shall be binding upon the court. However termination of the claim does not mean the court is bound by the legal title named by the party. The court may decide in favour of the claim, in the case facts presented by the party establish the claim on another legal title.

The principle of termination of the claim is not entirely applicable in cases of invalidity, because the content of claim of the party is not binding upon the court by resolving the legal consequences of invalidity. However, the court shall not prescribe such a consequence that is protested by all parties.

In the case of a contract being challenged, termination of a claim prevails even with regard to the legal title, because the court shall not examine a kind of ground for avoidance ex officio which was not referred by the party.

Upon the Code of Civil Procedure entered into force, Curia adopted the uniformity decision no. 1/2017 PJE to review the guiding principles of procedural law following the new Code of Civil Procedure entered into force. In the question of invalidity of contracts Curia has continued the relevance of civil department opinion 1/2005 (VI.15.) PK, which shall be applied in accordance with the rules of new Civil Procedure Code in the future. Curia has not continued the relevance of civil department opinion 2/2010. (VI.28.) PK for the purposes of the new Code of Civil Procedure, but Uniformity Panel emphasized that legal arguments, arguments, theoretical findings described in this opinion continued to be taken into account, if they are not contrary to the spirit of rules of the new Civil Procedure Code.

In administrative actions identity rights and content elements of statement of claim also differ from the rules applied in civil matters.

In administrative actions regulated in Charter XX of the Code of Civil Procedure of 1952 the content elements of statement of claim are differ from rules applied in civil actions while these actions in a point of fact purport to be review an administrative proceeding and administrative decision as result of it whether can be considered as an infringement of law or not. According to the Section 330 (2) of Code 
of Civil Procedure of 1952 in administrative activities a claim to review an administrative decision shall be submitted upon alleging infringement. From this provision, as a general rule, came that plaintiff has to name exactly the legal provision he thought to be infringed, and based on which he could claim for abolishing or reversion of administrative decision.

Upon department opinion 2/2011. (V.9.) KK however, the statement above shall be clarified to be correct. A claim for review of an administrative decision shall be based on an infringement of law. As a general rule, infringement of law stated by the plaintiff gives the limits to the court, within it could review the administrative decision. If the court does not found the infringement stated in the claim committed, it shall not abolish or reverse administrative decision based on another infringement of law differ in merit, as stated in the claim. Judicial review of the administrative decision is not exhaustive; its direction is identified by the breach of law stated by the plaintiff. In vain would find the court the defendant's decision an infringement of law by other reason, it shall not base the judgment. Only reasons for nullity could be taken into account ex officio as an exception.

Plaintiff within the infringement of law could name an exact legal provision, but it does not mean, this statement is binding upon the court. In particular, statement of the party is not binding upon the court if it is based on a mistake or it does not cover the true will of the party. It is not an obstacle to the review if the plaintiff submit the claim without indicating a specific legal provision his claim is based on, but breach of law can be clearly established from other circumstances of claim. In administrative activities the principle, according to which the court shall take into consideration the requests and statements made by the parties according to their content, is also applicable.

According to the Section 12 of the Code of Administrative Court Proceeding came into force on the 1 January 2018 the administrative and labour courts has general jurisdiction, upon Section 26 (1) referring to the Code of Civil Procedure, the rules of representation are the same in Code of Civil Procedure, from which it follows that in administrative actions administrative and labour court proceeds as the court of first instance, legal representation is not mandatory. As plaintiff is not obliged to take legal representation, Code of Administrative Court Proceeding also imposes much less stringent requirements on the mandatory contents of the claim, Section 37 (1) concludes the minimum contents in seven points. According to the Section 39 (2) plaintiff is not represented by a legal counsel shall also submit it by using a standard printed form according to the $21 / 2017$. (XII. 22.) Ministerial decree of Ministry of Justice, but unlike in Civil Procedure Code the application of this form is only optional, not mandatory.

It is important to emphasize that at the determination of mandatory contents of the claim named in Section 37 (1) of the Code of Administrative Court Proceeding, legislator basically vindicates the content of opinion 2/2011. (V. 9.) KK, sithence according to point $\mathrm{f}$ ), plaintiff shall indicate in his claim the infringement of law caused by administrative activity, including a description of the circumstances invoked as the basis of the claim and a description of the evidence supporting the claim. Ignoring it results in rejecting the claim under Section 48 (1) k) of Code of Administrative Court 
Proceeding. The Ministerial Justification of that Code adds: The Code uses the terminology of injuria instead of breach of law, while it wants to refer to that the exact description of legal situation could substitute the name of specific infringed legal provision. It comes from the principle of evaluation based on content that injuria could be duly exact in case of using inaccurate or missing marking of the legal provision.

According to Section 37 (1) g) of the Code of Administrative Court Proceeding plaintiff shall indicate in his claim the plea for court decision, which has correspond with the rules of Section 38 of Code of Administrative Court Proceeding, as Section 38 determines all the types of claims may be indicated in administrative activities. Plaintiff shall choose one of the opportunities listed in a)-f) points of Section 38 (1). It complies with the legal provisions if the plaintiff states that the administrative decision breaches law, and with that regard he claim for reversion or abolition of it in line with of Section 38 (1) a) of the Code. Within point a) plaintiff does not have to make any other choice, or rather he claims for abolition of administrative action it does not mean the court is not entitled to reverse it.

The principle of disposition, and within that the principle of binding force of claims has a different content in administrative actions as in the Civil Procedure Code. Section 85 of the Code of Administrative Court Proceeding provides, among the limitations of court decision, that a court shall examine the legality of an administrative activity within the limits of the claim. So administrative litigation essentially based on subjective legal protection. Besides the principle of disposition, however, officiality also plays an important supplementary role to ensure the function of objective legal protection. Thus a court shall take into account of its own motion the provisions of Section 85 (3) of the Code of Administrative Court Proceeding: e.g. nullity or other statutory case of avoidity of administrative activity in question, or if the legal basis of an administrative activity is not applicable. The court shall inform the parties on ordering an ex officio inquiry, and give them the opportunity to submit the comments, evidence, evidentiary motions.

Principle of disposition in administrative activities is specific in the manner, that court is not bound by the claim of plaintiff in the sense, that it reverses or abolishes unlawful administrative action. ${ }^{21}$ The Code of Administrative Court Proceeding puts on a new basis the reformatory power of court: It allows the reversion of unlawful administrative action not only upon statutory authorisation, but offers it as a general option of decision in compliance with Section 90 of the Code of Administrative Court Proceeding.

Considering the outcome of procedural law reform, in the claims submitted after 1 January 2018, we could make the conclusion that it is easier to answer the question of identity of rights in comparison of judgements made in administrative actions and civil cases. The court make its judgment in connection with an administrative activity, whether it is lawful or not, on the basis of infringement of law, while in a civil case where the question is the invalidity of a contract, plaintiff have to state the right, which is binding for the court. On the basis of that consideration, we

${ }^{21}$ Kiss Daisy: Közigazgatási perek, in: Németh János - Kiss Daisy (edit.): A polgári perrendtartás magyarázata, Budapest, CompLex Kiadó, 2010, 1320. 
could make the conclusion that if somebody initiate an administrative action in connection with a land sales contract, then the force of law of the judgment made in the administrative court proceeding excludes the plaintiff in a later civil procedure to state the sales contract shall be considered null and void on account of the infringement of regulations, since it is based on the same law. The agricultural administration body shall on the basis of Section 23 (1) a) of Land Transaction Act, examine invalidity within the administrative procedure, and the legality of this examination could be debated in the administrative court action.

At the same time, to found substantive force beside identity of rights, it is also required to identify the facts and parties. Identity of the parties cannot be established between administrative court proceeding and civil procedure for the declaration of invalidity of a contract, nor could be excluded the plaintiff of the civil procedure initiates other fact in his claim. The final conclusion could be drawn from this reasoning that from the perspective of legal institution of substantive force there is no procedural obstacle to submit a claim for the declaration of invalidity of a contract in a civil procedure after the administrative court make its own judgement.

\section{Principle of free deliberation of relevant facts of a case}

Due to parallel entry into force of the Code of Administrative Court Proceeding and of the Code of Civil Procedure, we may run into several provisions regulating the relationship between these two acts. Such a provision may be found under Section 264 of the Code of Civil Procedure on the free establishment of relevant facts of a case.

In connection with the principle of free establishment of relevant facts of a case, Section 263 (2) of the Code of Civil Procedure provides, as a general rule, that the court, in rendering its decision, shall not be bound by the decision of any body or by any disciplinary decision, nor by the facts contained therein. However, there are exceptions from this general rule, i.e. there are limitations in establishing of relevant facts of a case: Section 264 (2) of the Code of Civil Procedure provides that the final decision of the court of competence for administrative actions concerning the legality of public administration activities shall be binding upon the court hearing a case governed under this Act. This provision shall limit a civil court related to the legal qualification expressed in the final decision of an administrative court. Therefore, a civil court shall not reach such a conclusion that a court having proceeded in an administrative court proceeding misjudged the examined administrative activity lawful or unlawful.

This relative restriction raises interesting issues in connection with answering the questions emerged by this paper. Notwithstanding, if the court had examined the matter of breaching of statutory provision by a sales contract related to agricultural land in an administrative court proceeding, and it made a conclusion, that this contract shall not breach any statutory provisions, then, based on the same relevant facts of a case, neither a civil court shall not reach a divergent conclusion. Otherwise, this civil court would find, indirectly, that the administrative activity shall breach a statutory provision (that is, the approving clause of the agricultural administrative body). 
On the other hand, the provision under Section 264 (2) of the Code of Civil Procedure may not give a reassuring answer to us neither in the future, as this provision was basically introduced, because, under Section 6:548 (2) of the Civil Code, initiation of a proceeding for compensation of damages caused within the scope of administrative jurisdiction shall have a procedural condition, namely, a court shall declare in a final judgment the unlawfulness of an administrative activity under Section 24 (3) of the Code of Civil Procedure. ${ }^{22}$

In proceedings for compensation of damages caused within the scope of administrative jurisdiction, the legislature divided competence between a civil court and an administrative court, and the civil court shall be bound by the final decision of the administrative court.

\section{Concluding remarks}

After the introduction of procedural reforms, it may be concluded again that issues emerging from the possibility of initiating parallel proceedings may still not be unambiguously solved. From the point of view of procedural law, there is no objection before an injured party in initiating a civil proceeding to declare the contract null and void by the court, even on the same legal basis, after the settlement of an administrative court proceeding had entered into effect. On the other hand, a civil court may not come to a divergent legal conclusion from that having reached by an administrative court. Nonetheless, it may occur that such new facts emerge during a civil proceeding, which, with attention to the different legal character of the proceedings, were not examined neither by an administrative body in an administrative procedure, nor by the court in an administrative court proceeding, and which may result in a different legal qualification.

22 Pribula László: Joghatóság, hatáskör, illetékesség; in: Nagy Adrienn - Wopera Zsuzsa (edit.): Polgári eljárásjog I., Budapest, Wolters-Kluwer Kiadó, 2017, 68. 
NAGY Adrienn*

Változások a földforgalmi törvényhez kapcsolódó bírósági joggyakorlatban az eljárásjogi törvények reformja után ${ }^{* *}$

\section{Bevezető gondolatok}

2014. április 30-án lejárt Magyarország ún. földmoratóriuma az Európai Unión belül. A termőföld ugyanakkor stratégiai fontosságú erőforrásunk, melynek jogi védelme alapvetően indokolta egy olyan sarkalatos törvény megalkotását, amely szabályozza, hogy Magyarországon ki és milyen feltételekkel juthat termőföldhöz. Ennek eredményeként került elfogadásra a 2013. évi CXXII. törvény a mező- és erdőgazdasági földek forgalmáról (a továbbiakban: Földforgalmi törvény vagy Fftv.).

A Földforgalmi törvényt a hatályba lépése óta több alkalommal módosították, pontosították, és a kapcsolódó bírósági esetjog is szerteágazó. Jelen tanulmány célja elsődlegesen az eljárások egymás utániságának tisztázása a termőföld tulajdonjogának átruházása esetén ${ }^{1}$, különös tekintettel az eljárásjogi reformokra, azaz a polgári perrendtartásról szóló 2016. évi CXXX. törvény (a továbbiakban: Pp.) és a közigazgatási perrendtartásról szóló 2017. évi I. törvény (a továbbiakban: Kp.) 2018. január 1-ei hatályba lépésére. A tanulmány alapvetően arra a kérdésre is választ keres, hogy a termőföldek tulajdonszerzése kapcsán a bíróság előtti jogérvényesítésben milyen alapvető változások következhetnek be, nehezebb vagy könnyebb lesz a jogérvényesítés a szerződő felek számára.

\section{Problémafelvetés}

Az Fftv. hatálya alá tartozó termőföld tulajdonjogának adásvételi szerződés útján történő átruházása esetén az ingatlan-nyilvántartási eljárást megelőzi egy jegyzői hatáskörbe tartozó eljárás a törvényben biztosított elővásárlási jog gyakorolhatósága érdekében, majd a mezőgazdasági igazgatási szerv hatáskörébe tartozó közigazgatási eljárás, melynek célja a vevő szerzőképességének vizsgálata, valamint több elővásárlási jogot gyakorló közül az Fftv.-nek megfelelő vevő kijelölése. Az adásvételi szerződést

Adrienn Nagy: Changes in judicial practice related to the land transaction act after reforms of procedural acts - Változások a földforgalmi törvényhez kapcsolódó bírósági joggyakorlatban az elárásjogi törvények reformja után. Journal of Agricultural and Environmental Law ISSN 1788-6171, 2018 Vol. XIII No. 25 pp. 132-156 doi: 10.21029/JAEL.2018.25.132

* dr. jur., PhD intézetigazgató egyetemi docens, Miskolci Egyetem Állam- és Jogtudományi Kar, Európai és Nemzetközi Jogi Intézet, e-mail: jogadri@uni-miskolc.hu

** A tanulmány az Igazságügyi Minisztérium jogászképzés szinvonalának emelését célzó programjai keretében valósult meg.

1 A problémafelvetés Olajos Istvántól származik; lásd Olajos István: Mezőgazdasági földterületek tulajdonszerzése és hasznosítása, különös tekintettel a formálódó magyar bírósági gyakorlatra, Agrár-és Körmyezetjog, 2017/23, 105, doi: 10.21029/JAEL.2017.23.91. 
biztonsági okiratba kell foglalni, melyet jóváhagyó záradékkal (határozattal) lát el a mezőgazdasági igazgatási szerv. Az ingatlan-nyilvántartási eljárásban ezt követően már csak az Inytv.-ben (1997. évi CXLI. tv.) előírt szempontok meglétét szükséges vizsgálni. ${ }^{2}$

Ha a mezőgazdasági igazgatási szerv a közigazgatási eljárás keretében megtagadja az adásvételi szerződés jóváhagyását az Fftv. 23. \-a alapján, döntése ellen a közigazgatási eljárás keretében fellebbezésnek helye nincs, jogorvoslatként csak a döntés bírósági felülvizsgálata kérhető, azaz közigazgatási per kezdeményezhető. ${ }^{3}$ A közigazgatási per kezdeményezésének lehetősége ugyanakkor nem zárja ki az adásvételi szerződés kapcsán a Polgári Törvénykönyvről szóló 2013. évi V. törvény (a továbbiakban: Ptk.) alapján érvénytelenség megállapítása iránti polgári per kezdeményezését sem.

Önmagában a közigazgatási per és a polgári per párhuzamos kezdeményezésének lehetősége nem vetne fel problémát, hiszen a két per célja eltérő jellegű: a közigazgatási per tárgya a közigazgatási cselekmény jogszerűségének tisztázása a Kp. szabályai szerint, míg a polgári per alapvetően a szerződés érvényességének megítélését célozza a Pp. szabályai alapján. A problémát az Fftv. 23. \$(1) bekezdésének a) pontja veti fel, melynek alapján a mezőgazdasági igazgatási szervnek a termőfölddel kapcsolatos adásvételi szerződés közigazgatási eljárás keretében történő vizsgálata során azt is figyelembe kell vennie, hogy az adásvételi szerződés a jogszabályi előírások megsértése miatt létre nem jött szerződésnek, vagy semmis szerződésnek minősül, és amennyiben ez megállapítható, a jóváhagyást meg kell tagadnia. A közigazgatási eljárást követően kezdeményezett közigazgatási perben pedig előfordul, hogy a felperes ezen szakaszra hivatkozva kéri a közigazgatási határozat jogszabálysértő voltának megállapítását, és hivatkozik a Ptk. érvénytelenséggel kapcsolatos rendelkezéseire is. ${ }^{4}$ Kizárt-e ez esetben az adásvételi szerződés megtámadása polgári perben a Ptk. szabályai szerint arra hivatkozva, hogy az adásvételi szerződés nem jött létre, vagy semmis a jogszabályba ütközés okán.

Eljárásjogi szempontból e kérdés megválaszolása alapvetően két jogintézmény elemzése útján kísérelhető meg: az anyagi jogerô és a tényállás szabad megállapításának elve útján.

\section{Az eljárásjogi reformokról, avagy változások a jogsértő közigazgatási cselekmény felülvizsgálatában}

A problémafelvetés megválaszolása előtt elengedhetetlen néhány szót szólni azokról az eljárásjogi reformokról, melyek 2018. január 1-jétől jelentős változást hoznak a pereskedők életében. Korábban a polgári perrendtartásról szóló 1952. évi III. törvény (a továbbiakban: 1952-es Pp.) XX. Fejezete szabályozta a közigazgatási pereket, míg a szerződések érvénytelenségének megállapítása iránti perek az 1952-es Pp. általános szabályai szerint zajlottak. 2018. január 1-étől viszont a közigazgatási perekre a Kp., a

\footnotetext{
2 Olajos 2017, 105.

${ }^{3} \mathrm{Fftv}$. 30. \(5) bek.

${ }^{4}$ Lásd pl. a Kúria Kfv.III.37.681/2016. sz. ügyben hozott ítéletét.
} 
polgári perekre a Pp. szabályai vonatkoznak. A két eljárásjogi törvény eltérő szemléletmód alapján szabályozza a peres eljárásokat, melyet a tanulmány későbbi fejezetei is szemléltetnek.

A Kp. hatálybalépését követően a Földforgalmi törvénnyel összefüggésben kezdeményezett közigazgatási per megindítása, lefolytatása, illetve a közigazgatási perben hozott ítélet elleni perorvoslati lehetőségekben is változások következtek be.

Az Fftv. 30. \ (5) bekezdése alapján a mezőgazdasági igazgatási szerv határozata ellen a közigazgatási eljárás keretében fellebbezésnek helye nincs, az egyetlen jogorvoslati lehetôség a közigazgatási per megindítása.

Közigazgatási per kezdeményezése esetén a jogsértés korrigálása elsődlegesen a közigazgatási szervezetrendszeren belül történik: ha a keresetlevél alapján ${ }^{5}$ a hatóság megállapítja, hogy döntése jogszabályt sért, azt módosítja vagy visszavonja; ha a keresetlevélben foglaltakkal egyetért és az ügyben nincs ellenérdekű ügyfél, a hatóság a nem jogszabálysértő döntést is visszavonhatja, illetve a keresetlevélben foglaltaknak megfelelően módosíthatja. ${ }^{6}$

Amennyiben a közigazgatási szerv saját hatáskörében nem vonta vissza vagy nem módosította a sérelmezett döntést, úgy a közigazgatási jogvitát a közigazgatási ügyben eljáró bíróság bírálja el; ez esetben a keresetlevelet továbbítani kell a hatáskörrel és illetékességgel rendelkező közigazgatási és munkaügyi bírósághoz. A Kp. 12. \-a határozza meg az általános hatáskörű bíróságot, mely a közigazgatási és munkaügyi bíróságot jelenti, míg a Kp. 13. \-a szerint az illetékesség szempontjából a szerződéssel érintett ingatlan fekvése lesz irányadó azzal, hogy a Kp. alapján csak a kijelölt nyolc közigazgatási és munkaügyi bíróság járhat el ezekben az ügyekben regionális illetékességgel. ${ }^{7}$

A Kp. hatályba lépése a közigazgatási perben hozott elsőfokú ítélettel szembeni fellebbezés megengedhetőségét illetően alapvető változást nem hozott.

Az 1952-es Pp. 340. \ (1) bekezdése is általános jelleggel kizárta a fellebbezés lehetőségét a közigazgatási perben hozott ítélettel szemben. A bíróság ítélete ellen fellebbezésnek csak abban az esetben volt helye, ha a Pp. 340. \(2) bekezdésében írt két feltétel együttesen megvalósult, nevezetesen: (a) a közigazgatási pert olyan elsőfokú határozat bírósági felülvizsgálata iránt indították, amely ellen közigazgatási úton nincs helye fellebbezésnek, és (b) a bíróság a közigazgatási határozatot törvényi felhatalmazás alapján megváltoztathatja.

A Földforgalmi törvény alapján a mezőgazdasági igazgatási szerv által hozott határozat bírósági felülvizsgálata során a bíróság elsőfokú ítélete ellen a fellebbezés azért

\footnotetext{
${ }^{5}$ A Kp. 39. \(1) bekezdése szerint ugyanis közigazgatási per kezdeményezése esetén a felperes továbbra is a közigazgatási szervnél köteles benyújtani a keresetlevelét, ebben az értelemben változás nem következett be.

6 Pribula László: Közigazgatási perek, in: Nagy Adrienn - Wopera Zsuzsa (szerk.): Polgári eljárásjog II., Budapest, Wolters Kluwer Kiadó, 2018, megjelenés alatt.

7 A közigazgatási perben elsőfokon főszabály szerint nyolc „kiemelt" státuszú közigazgatási és munkaügyi bíróság jár el, az egyes bíróságokhoz 1-3 megye illetékességi területét rendelve. E kiemelt közigazgatási és munkaügyi bíróságok a következők: Fővárosi, Budapest Környéki, Debreceni, Győri, Miskolci, Pécsi, Szegedi, Veszprémi Közigazgatási és Munkaügyi Bíróság.
} 
volt megengedett már az 1952-es Pp. szabályai szerint is, mert az Fftv. kizárta a fellebbezés lehetőségét a közigazgatási eljárás keretében, és a mező- és erdőgazdasági földek forgalmáról szóló 2013. évi CXXII. törvénnyel összefüggő egyes rendelkezésekről és átmeneti szabályokról szóló 2013. évi CCXII. törvény 39. 『-a biztosította a reformatórius jogkört a bíróság számára.

A közigazgatási perben hozott ítélet elleni fellebbezés főszabálykénti kizárását a Kp. 99. \ (1) bekezdése is fenntartotta, mely alapján fellebbezésnek a bíróság ítéletével szemben csak akkor van helye, ha maga a Kp. vagy más törvény azt lehetővé teszi. A 2017. évi L. törvény (Ákr. és Kp. saláta törvény) a 2013. évi CCXII. törvény 39. 』-át akként módosította, hogy a bíróság elsőfokú ítélete ellen - kivéve a mezőgazdasági igazgatási szerv hatósági bizonyítványa ellen indított közigazgatási perben hozott elsőfokú ítéletet - fellebbezésnek van helye, melynek elbírálására a Kp. 13. \ (11) bekezdése értelmében a Fővárosi Törvényszéknek van kizárólagos illetékessége.

Valódi változást a Kp. hatályba lépése a felülvizsgálat megengedhetôsége körében hozott. Az 1952-es Pp. 340/A. \(1) bekezdése alapján ugyanis a felülvizsgálat megengedett volt az elsőfokon jogerőre emelkedett bírósági ítélettel szemben. Erre figyelemmel a felülvizsgálat „átvette” a rendes perorvoslat funkcióját sok esetben, figyelemmel arra is, hogy a közigazgatási perben előterjesztett keresetlevélben is jogszabálysértésre kellett hivatkozni, és a felülvizsgálati kérelemnek is kötelező eleme volt a jogszabálysértés megjelölése.

A Kp. 118. \-a alapján ugyanakkor a közigazgatási perekben hozott ítélet elleni felülvizsgálat előterjeszthetősége komoly feltételekhez kötött. A felülvizsgálati kérelemben ugyanis az ügy érdemére kiható jogszabálysértés megjelölése mellett még az alábbi szempontok egyikére is hivatkoznia kell a félnek: az ügy érdemére kiható jogszabálysértésnek a vizsgálata (a) a joggyakorlat egységének vagy továbbfejlesztésének biztosítása, (b) a felvetett jogkérdés különleges súlya, illetve társadalmi jelentősége, (c) az Európai Unió Bírósága előzetes döntéshozatali eljárásának szükségessége, vagy (d) a Kúria közzétett ítélkezési gyakorlatától eltérő ítéleti rendelkezés miatt indokolt.

A Kúria háromtagú tanácsa a felülvizsgálati kérelem felterjesztését követően elsődlegesen azt vizsgálja meg tárgyaláson kívül 30 napon belül, hogy a felülvizsgálati kérelem e feltételeknek megfelel-e, azaz a felülvizsgálati kérelem befogadhatóságáról dönt. E törvényi szigorítás jelentős kihatással lesz a Földforgalmi törvény kapcsán alakuló bírósági joggyakorlatra, hiszen csak kivételes esetekben jut el egy bírósági ügy a Kúriához úgy, hogy a felülvizsgálati eljárás keretében azzal érdemben foglalkozzon. Mindez azt is eredményezi, hogy az elsőfokon döntő közigazgatási és munkaügyi bíróságokra, illetve a másodfokon eljáró Fővárosi Törvényszékre nagyobb felelősség hárul a szakmailag helyes döntés meghozatalát illetően.

\section{A probléma megválaszolása az anyagi jogerő vizsgálatán keresztül}

A tanulmány 2. pontjában felvetett probléma megoldását megkísérelhetjük az anyagi jogerő jogintézményének elemzésén keresztül. Az alapproblémát annak a kérdésnek a megválaszolása jelenti, hogy a közigazgatási perben hozott ítélethez kapcsolódó anyagi jogerô kizárja-e, korlátozza-e a szerződések érvénytelensége körében a polgári per megindítását. 
Az anyagi jogerő fogalmát mind a Kp., mind a Pp. meghatározza. A Kp. 96. \-a értelmében a közigazgatási tevékenység jogszerüségének vizsgálata tárgyában hozott itélet jogereje kizárja, hogy ugyanazon közigazgatási tevékenység jogszerüségének vizsgálatára a felek vagy az. érdekeltek új keresetet indíthassanak vagy azt egyébkeént vitássá tehessék. A Kp. tehát e fogalmat elsődlegesen a közigazgatási perek relációjában szabályozza, és az anyagi jogerô megállapíthatóságához a felek és a per tárgyává tett közigazgatási cselekmény azonossága szükséges.

A Pp. 360. S (1) bekezdése az anyagi jogerő kapcsán a következóképpen fogalmaz: A keresettel és az ellenkövetelés fennállta tekintetében érdemben elbirált beszámitással érvényesitett jog tárgyában hozott itélet jogereje kizárja, hogy ugyanabból a tényalapból származó ugyanazon jog iránt ugyanazok a felek - ideértve azok jogutódait is - egymás ellen uj keresetet indithassanak, vagy az itéletben már elbirált jogot egymással szemben egyébként vitássá tehessék. A polgári perekben az anyagi jogerőnek alapvetően három feltétele van: a félazonosság, a tényazonosság és a jogazonosság.

A tanulmány tárgyát képező probléma megoldása kapcsán alapvetően annak a kérdésnek a megválaszolása emelhető ki, hogy megállapítható-e a jogazonosság a közigazgatási perben, illetve a polgári perben hozott ítélet kapcsán. A kérdés megválaszolásához pedig alapvetően a keresetlevél tartalmából kell kiindulnunk, mellyel összefüggésben alapvető változások következtek be az eljárásjogi reformok után.

Az 1952-es Pp. 121. \(1) bekezdése - a legutolsó hatályossági állapota alapján ${ }^{8}$ - mindössze öt pontban foglalta össze a keresetlevél kötelező tartalmi elemeit. Az 1952 es Pp. 121. \ (1) bekezdésének c) pontja szerint a felperes köteles a keresetlevélben megjelölni az érvényesíteni kívánt jogot, az annak alapjául szolgáló tényeknek és azok bizonyítékainak előadásával. E törvényi rendelkezés kapcsán alakult ki a bírósági joggyakorlatban és a jogirodalomban a jogcímhez kötöttség vagy kereseti kérelemhez kötöttség dilemmája. ${ }^{9}$ A joggyakorlat szerint az 1952-es Pp. alapján az érvényesíteni kívánt jog megjelöléséhez nem feltétlenül volt szükség arra, hogy azt a felperes konkrét jogszabályhelyre utalással tegye meg. A felperes az érvényesíteni kívánt jog megjelölésével hozza a bíróság tudomására azt, hogy mi az a jog, amely alapján a másik féllel szemben valamely követelése áll fenn, irányt mutat a bírósági döntéshez vezető úton. A felperesnek az érvényesíteni kívánt jogot az annak alapjául szolgáló tényeknek és bizonyítékainak előadásával kell megjelölnie, azaz kronológiai sorrendet követve elő kell adnia az adott ügy szempontjából jogilag releváns valamennyi tényt, melyeket az általa felajánlott bizonyítási eszközök útján igazol. Azért is fontos a tények pontos és részletes megjelölése, mivel a bíróság ítéletét csak a peres felek által előadottakra alapíthatja, sőt az 1952-es Pp. kapcsán egyre inkább megerősödött azon bírói gyakorlat, mely szerint a felperes (és az alperes) által előadott tényállásból a bíróság a felperes által

8 A 2005. évi CXXX. törvény a keresetlevél kötelező tartalmi elemei körét bővítette egy hatodik elemmel, mely szerint a keresetlevélben a felperes köteles volt arra is kitérni, hogy a jogvitában a peres felek között volt-e közvetítői eljárás folyamatban, kivéve azokat a pereket, melyekben a közvetítést törvény kizárja. Ez a rendelkezés 2008. december 31-ig volt hatályban, a 2008. évi XXX. törvény hatályon kívül helyzete 2009. január 1. napjától.

9 Erről lásd részletesen Pákozdi Zita: A jogerô tárgyi terjedelme a polgári perben, $\mathrm{PhD}$ dolgozat, Szeged, 2015. 
előadott jogtól eltérő, a tényelőadásból levezethető jog alapján hoz ítéletet. ${ }^{10} \mathrm{Ez}$ azt is jelenti, hogy a felperes helytelen jogcímmegjelölése még nem eredményezhette a kereset elutasítását, ha a jó jogcím, a helyes jogi minősítés megállapításához valamennyi tény, bizonyíték, adat rendelkezésre állt. ${ }^{11} \mathrm{Az}$ 1952-es Pp. alapján tehát a polgári perre vitt jogviták elbírálása két alappilléren állt: a tényálláson és a kereseti kérelmen. Ezt az értelmezést az 1952-es Pp. 215. J-ának azon rendelkezése is alátámasztotta, hogy a bíróság érdemi döntésének csak a kereseti kérelem képezi a korlátját.

A 2018. január 1-étől hatályos Pp. szabályai jelentős szigorítást hoztak, a Pp. 170. \-a részletesebben sorolja föl a keresetlevél kötelező tartalmi elemeit. A fél rendelkezési jogára hangsúlyosabban építő új szabályozás változtat az 1952-es Pp. tartalmi követelményein, és új elemként megköveteli a keresettel érvényesíteni kívánt jog nevesítését, valamint a jogi érvelés előterjesztését. Így a jogvita elbírálása immáron bárom alappilléren nyugszik: tényállás - kereseti kérelem - a felperes jogállítása. A három pillér közötti logikai összefüggést kell levezetnie a felperesnek a jogi érvelés keretében. ${ }^{12}$ Ez a szigorítás alapvetően azzal magyarázható, hogy a Pp. elsőfokú eljárásának szabályozása a törvényszéket tekinti általános hatáskörű bíróságnak, ahol az eljárás folyamán valamennyi fél számára, illetve az első, a másodfokú, illetve a rendkívüli perorvoslati szakban is kötelező a jogi képviselet. Ha a keresetlevelet jogi szakvizsgával rendelkező jogi képviselő készíti el, szakmailag elvárható tőle a jogállítás pontos megjelölése. Az érvényesíteni kívánt jog megjelölésének követelménye azért is fontos, mert a perfüggőség, illetve az anyagi jogerőhatás egyik viszonyítási pontja. ${ }^{13}$

Az ítélkezés kiszámíthatósága és a tisztességes eljárás érdekében a Pp. 170. 『-a kötelezővé tette az érvényesíteni kívánt jog egyértelmű nevesítését a keresetlevélben. A jövőben tehát az érvényesíteni kívánt jogot nem az előadott tények alapján kell a bíróságnak megállapítania. A Pp. 342. \(3) bekezdése alapján a bíróság a fél által megjelölt joghoz, azaz a jogállításhoz is kötve van döntése meghozatalakor. Az érvényesített joghoz kötöttség és az anyagi igazság érvényesülése közötti esetleges feszültséget lényegesen enyhíti az anyagi pervezetés új jogintézménye. ${ }^{14}$

A Pp. 7. \-a az értelmező rendelkezések között határozza meg a jogállítással kapcsolatban használt két legfontosabb fogalmat: a keresettel érvényesíteni kívánt jogot és a jogalapot. A felperes a jogállítását alapvetően két módon teheti meg: egyrészt a jog alapjául szolgáló konkrét jogszabályhely megjelölésével [pl. Ptk. 6:535. \ (1) bek.], másrészt a jog alapjául szolgáló jogszabályi rendelkezés tartalmának megnevezésével (pl. veszélyes üzemi felelősségből eredő kár megtérítése iránti jog). ${ }^{15}$ Önmagában annak

${ }_{10}$ Nagy Andrea: Eljárás az elsőfokú bíróság előtt, in: Wopera Zsuzsa (szerk.): Polgári perjog általános rész, Budapest, CompLex Kiadó, 2008, 301.

${ }^{11} \mathrm{EBH} 2004.1143$.

12 Vö. Wopera Zsuzsa: Az új polgári perrendtartás karakterét adó egyes megoldások európai összehasonlításban, ADVOCAT, 2017/klnszm, 6.

13 Wallacher Lajos: Perindítás, in: Wopera Zsuzsa (szerk.): Kommentár a polgári perrendtartásról szóló 2016. évi CXXX. törvényhez, Budapest, Magyar Közlöny Lap- és Könyvkiadó Kft, 2017, 351.

14 Zsitva Ágnes: Perindítás, in: Wopera Zsuzsa (szerk.): A polgári perrendtartásról szóló 2016. évi CXXX. törvény magyarázata, Budapest, Wolters Kluwer Kiadó, 2017, 255-256.

15 Zsitva 2017, 256. 
feltüntetése, hogy a megtámadott szerződés érvénytelen, nem felel meg a törvényi követelményeknek.

A Pp. szabályainak szigorát oldja az a rendelkezés, mely szerint, ha a polgári per elsőfokon a járásbíróságon indul, főszabály szerint nem kötelező a jogi képviselet. Ha a felperes a keresetlevelét ez esetben jogi képviselő nélkül terjeszti elő, a Pp. 246. S (1) bekezdése értelmében azt a 21/2017. (XII. 22.) IM rendelet által rendszeresített nyomtatványon kell benyújtania azzal, hogy a Pp. 247. \-a értelmében nem kell feltüntetnie a jogalapot, a jogi érvelést és jogszabályhelyet. A jogalap mellőzése azonban nem jelenti azt, hogy a félnek nem kell jogállítást tennie. Csupán azt jelenti, hogy a jogi képviselet hiányában nem kell professzionális jogállítást tennie. A jogi képviselő nélkül eljáró fél jogállítása vonatkozásában az az eltérés, hogy ő az érvényesített jogot kifejezésre juttathatja más alkalmas módon is, feltéve, hogy abból a jogalap beazonosítható. Ez azonban nem azonos az 1952-es Pp. 121. S(1) bekezdésének c) pontja szerinti megközelítéssel és gyakorlat fenntartásával. ${ }^{16}$ Ezért is célszerű a Pp. 246. $\int$ (2) bekezdésében írt lehetőség kihasználása: nevezetesen a bírósági panasznapon a keresetlevél szóbeli előadása, melynek következtében az IM rendelet által rendszeresítetett nyomtatványt a bíróság tölti ki. ${ }^{17}$

A polgári perekben az érvényesíteni kívánt jog és az ezzel összefüggő kérdések speciális területének tekinthetők a szerződések érvénytelenségével kapcsolatos perek. Speciális abban az értelemben, hogy nagy szerepet kapott a polgári eljárástól idegen hivatalbóli eljárás elve, másrészt egy idő után megjelent bizonyos értelemben az érvényesített joghoz kötöttség is. ${ }^{18}$

A szerződés érvénytelenségi okokat két nagy csoportba sorolhatjuk: a semmisségi és a megtámadási okokra. A semmisség az érvénytelenség súlyosabb esete, a semmisség megállapítására külön eljárás lefolytatására nincs szükség, és a bíróságnak a semmisségi okot hivatalból kell észlelnie. ${ }^{19}$ Ezzel ellentétben a megtámadási okok esetén a szerződés megtámadására a sérelmet szenvedett fél és az jogosult, akinek a megtámadáshoz érdeke fűződik, a megtámadási okot a másik féllel közölni kell egy éves határidőn belül, ha az eredménytelen, az igényt bírósági úton kell érvényesíteni, és a bíróságnak hivatalból nem kell figyelembe vennie a megtámadási okokat.

$\mathrm{Az}$ érvénytelenségi okokhoz füződő szankciók és jogkövetkezmények tekintetében azonban nincs különbség: az érvénytelen szerződésből joghatás nem következhet be, a jogkövetkezmény pedig lehet a szerződés érvényessé nyilvánítása, az eredeti állapot helyreállítása, és az alaptalan gazdagodás pénzbeli megtérítése. ${ }^{20}$

A régi Ptk. (1959. évi IV. törvény) elfogadásakor a semmisségi okok esetében a teljes hivatalbóliság érvényesült, és ez vonatkozott a jogkövetkezmények alkalmazására is. A Legfelsőbb Bíróság a PK 32. sz. állásfoglalásában a jogkövetkezmények

\footnotetext{
16 Zsitva 2017, 362.

${ }_{17}$ Fontos hangsúlyozni, hogy amennyiben a felperes jogi képviselővel terjeszti elő a járásbíróság elsőfokú hatáskörébe tartozó perben a keresetlevelet, ez a könnyebbség rá nem vonatkozik, a keresetlevélnek a Pp. 170. \-ában írtaknak kell megfelelnie.

18 Pákozdi 2015, 73.

${ }^{19}$ Ptk. 6:88. \ (1) bek.

${ }^{20}$ Pákozdi 2015, 74.
} 
tekintetében az eredeti állapot helyreállítását helyezte előtérbe. A PK. 32. sz. állásfoglalás alapján a bíróságnak a semmisségi okot nemcsak hivatalból kellett figyelembe vennie, de az érvénytelenség jogkövetkezményét is hivatalból kellett megállapítania.

E gyakorlaton változtatott az 1/2005. (VI.15.) PK vélemény, mely rögzítette, hogy az érvénytelenség jogkövetkezményét a bíróság csak erre irányuló kérelem esetén alkalmazhatja, hivatalból akkor sem, ha a semmisségi ok fennállását észleli. A hivatalból való észlelés ugyanis nem jelenthet kötelezettséget a bíróság számára, hogy kutatnia kellene az esetleges semmisségi okok után, de azt sem, hogy a feleket erre vonatkozóan bizonyításra hívja fel a semmisségi ok tisztázásához.

Az 1/2010. (VI.28.) PK vélemény 1. pontja végképp meghaladottá nyilvánította a PK 32. sz. állásfoglalást, és az érvénytelenség jogkövetkezményeiről a Legfelsőbb Bíróság Polgári Kollégiuma új iránymutatást adott ki. Ehhez kapcsolódóan az érvénytelenségi perekben felmerülő egyes eljárásjogi kérdésekről a 2/2010. (VI.28.) PK véleményt tette közzé, melyből az alábbiak kiemelése szükséges.

A félnek a szerződés érvénytelenségére alapított marasztalási kereseti kérelmében pontosan meg kell jelölnie, hogy az érvénytelenség melyik törvényi jogkövetkezményének alkalmazását milyen tartalommal kéri a bíróságtól.

A bíróságnak csak a rendelkezésre álló bizonyítási anyag alapján tényként egyértelműen megállapítható, nyilvánvaló semmisséget kell hivatalból észlelnie. A semmisség megállapíthatósága érdekében a bíróság hivatalból bizonyítást nem folytathat le. Ugyanígy hivatalból észlelnie kell a bíróságnak azt is, ha a szerződés nem jött létre. A bíróság a kereseti tényállásban előadottakhoz, valamint a kereset tárgyához általában kötve van. A kereseti kérelemhez kötöttség azonban nem jelenti azt, hogy a bíróság a fél által megjelölt jogcímhez is kötve van. A bíróság a fél kérelmének helyt adhat akkor is, ha a fél által előadott tények a kérelmet más jogcímen megalapozzák.

A kérelemhez kötöttség elve nem érvényesül maradéktalanul az érvénytelenségi perben, mert az érvénytelenség jogkövetkezményeinek levonása körében a fél kérelmének tartalma a bíróságot nem köti. A bíróság azonban nem alkalmazhat olyan jogkövetkezményt, amely ellen valamennyi fél tiltakozik.

A szerződés megtámadása esetén a kereseti kérelemhez kötöttség még a jogcímet illetően is érvényesül, a bíróság ugyanis hivatalból nem vizsgálhatja olyan megtámadási ok fennállását, amelyre a fél nem hivatkozott.

A Kúria a Pp. hatályba lépésével összefüggésben fogadta el az 1/2017. sz. Polgári jogegységi határozatot az eljárásjogi tárgyú elvi iránymutatásoknak az új Pp. hatályba lépése folytán történő felülvizsgálatáról. A szerződések érvénytelensége körében a Kúria az 1/2005. (VI.15.) PK véleményt tartotta fenn, melyet az új Pp. szabályaival összhangban a jövőben is alkalmazni kell. A 2/2010. (VI.28.) PK véleményt az új Pp.-vel összefüggésben nem tartotta fenn, de a jogegységi tanács hangsúlyozta, hogy a PK véleményben foglalt - az új Pp. szabályai szellemével nem ellentétes - jogi okfejtések, érvek, elvi megállapítások továbbra is figyelembe vehetők.

A közigazgatási perekben a jogazonosság megállapítása és a keresetlevél kötelező tartalmi elemei is eltérnek a polgári perekre irányadó szabályoktól. 
Az 1952-es Pp. XX. Fejezetében szabályozott közigazgatási perek esetében a keresetlevél kötelező tartalma a polgári perektől eltérően alakult, hiszen a per lényegét tekintve a közigazgatási eljárás és az annak eredményeként meghozott közigazgatási határozat jogszabálysértő voltának megítélésére irányult. Az 1952-es Pp. 330. \ (2) bekezdése értelmében a közigazgatási perben a közigazgatási határozat felülvizsgálata jogszabálysértésre hivatkozva kérhető. E rendelkezésből főszabályként az következik, hogy a felperesnek konkrétan meg kell jelölnie azt a jogszabályi rendelkezést, melynek megsértését állítja, és mely alapján kereseti kérelme a közigazgatási határozat hatályon kívül helyezésére vagy megváltoztatására irányul.

A 2/2011. (V.9.) KK vélemény alapján azonban ez az állítás némi pontosítással állja meg a helyét. A közigazgatási határozat bírósági felülvizsgálatát jogszabálysértésre hivatkozással lehet kérni. Főszabályként a felperes által megjelölt jogszabálysértés szabja meg a bíróság számára azokat a korlátokat, amelyek között a közigazgatási határozatot felülvizsgálhatja. Ha a bíróság a keresetlevélben megjelölt jogszabálysértést nem állapítja meg, más - a megjelölttől érdemben eltérő - jogszabálysértésre a közigazgatási határozat hatályon kívül helyezését vagy megváltoztatását nem alapíthatja. A közigazgatási határozat bírósági felülvizsgálata nem teljes körü, annak irányát a felperes által hivatkozott jogszabálysértés jelöli ki. Hiába találná a bíróság más okból jogszabálysértőnek az alperesi határozatot, arra nem alapíthatja a döntését. Ez alól csak a hivatalból figyelembe veendô semmisségi okok képeznek kivételt.

A felperes a jogszabálysértés körében konkrét jogszabályi rendelkezés megsértését is megjelölheti, ez azonban nem jelenti azt, hogy ehhez a megjelöléshez kötve van a bíróság. Különösen akkor nincs kötve a bíróság a fél nyilatkozatához, ha az tévedésen alapul, illetôleg nem fedi a fél valóságos akaratát. Nem akadálya a felülvizsgálatnak az, ha a fél a keresetlevélben nem jelöli meg azt a konkrét jogszabályhelyet, amelyre a keresetet alapítja, de keresetéből a kifogásolt jogszabálysértés egyértelmúen megállapítható. A közigazgatási perekben is érvényesül az az elv, amely szerint a kérelmeket, nyilatkozatokat tartalmuk szerint kell elbírálni.

A 2018. január 1-tôl hatályos Kp. 12. §-a szerint az általános hatáskörrel rendelkező bíróság a közigazgatási és munkaügyi bíróság, a képviseletre a Kp. 26. \ (1) bekezdésében foglalt utaló szabály alapján a Pp. képviseleti rendelkezéseit kell alkalmazni, melyből az következik, hogy azokban a közigazgatási perekben, melyek elsőfokon a közigazgatási és munkaügyi bíróságon indulnak, nem kötelező a jogi képviselet. Mivel a felperesnek nem kötelező professzionális képviselőt igénybe vennie, a keresetlevél kötelező tartalmi elemei körében is sokkal enyhébb követelményeket támaszt a Kp., a 37. \(1) bekezdése összesen hét pontban fogalmazza meg a minimális tartalmi elemeket. A Kp. 39. S (2) bekezdése alapján a jogi képviselő nélkül eljáró felperes a keresetlevelét előterjesztheti a 21/2017. (XII. 22.) IM rendelet által rendszeresített nyomtatványon is, de a Pp.-vel ellentétben a nyomtatvány csak választható, és nem kötelező annak alkalmazása. 
A Kp. 37. \(1) bekezdésében rögzített, a keresetlevél kötelező tartalmi elemei körében fontos hangsúlyozni, hogy a jogalkotó alapvetően a 2/2011. (V.9.) KK véleményben foglaltakat érvényesítette, hiszen a felperesnek az f) pont szerint a keresetlevélben meg kell jelölnie a közigazgatási tevékenységgel okozott jogsérelmet, az annak alapjául szolgáló tények, illetve azok bizonyítékai előadásával. Ennek mellőzése a Kp. 48. \$ (1) bekezdésének k) pontja szerint a keresetlevél visszautasítását eredményezi. Ehhez a Kp. Miniszteri indokolása hozzáteszi: A jogszabálysértés helyett a perrendtartás a jogsérelem fogalmat használja, amivel arra kiván utalni, hogy a jogi helyzet pontos körülírása belyettesitheti a konkerétan megsértett jogszabályhely megjelölését. A tartalom szerinti elbirálás elvéböl is követke zik, hogy a jogszabályhely pontatlan vagy hiányzó megjelölése esetén is lehet kellöen pontosan körülhatárolt a jogsértés mibenléte.

A Kp. 37. \ (1) bekezdésének g) pontja alapján a felperesnek a keresetlevélben ki kell térnie a bíróság döntésére irányuló határozott kérelemre is, melynek a Kp. 38. \$ában foglaltaknak kell megfelelnie. A Kp. 38. \-a ugyanis taxatíve meghatározza a közigazgatási perben előterjeszthető kereseti kérelmeket. A felperesnek a Kp. 38. 』 (1) bekezdésének a)-f) pontjaiban foglalt lehetőségek közül kell határozottan választania. Megfelel a törvényi rendelkezéseknek az, ha a felperes állítja, hogy a közigazgatási határozat jogszabálysértő, és erre tekintettel kéri annak megváltoztatását vagy hatályon kívül helyezését a Kp. 38. \(1) bekezdésének a) pontjára hivatkozva. Az a) ponton belül további választást a felperesnek nem kell eszközölnie, illetve ha a közigazgatási cselekmény hatályon kívül helyezését kéri, az nem fogja azt jelenteni, hogy a bíróság ne gyakorolhatná a megváltoztatási jogkört.

A rendelkezési elv, és azon belül a kérelemhez kötöttség elve azonban a Pp.ben rögzítettektől eltérô tartalommal érvényesül a közigazgatási perekben. A Kp. 85. \-a a bírósági döntés korlátai között említi meg, hogy a bíróság a közigazgatási tevékenység jogszerűségét a kereseti kérelem korlátai között vizsgálja. A közigazgatási bíráskodás tehát alapvetően a szubjektív jogvédelem talaján áll. A rendelkezési elv mellett azonban fontos kiegészítő szerep jut a hivatalbóliság elvének is az objektív jogvédelmi funkció biztosítása céljából. Így a bíróság a Kp. 85. S (3) bekezdésében foglaltakat hivatalból is figyelembe veszi: például a vitatott közigazgatási cselekmény semmisségi vagy törvényben meghatározott más érvénytelenségi okát, vagy a közigazgatási cselekménynek az ügyben nem alkalmazandó jogszabályi rendelkezésre alapítását. A bíróság a hivatalbóli vizsgálat elrendelésrôl köteles a feleket tájékoztatni, és köteles számukra lehetőséget biztosítani az észrevételek, bizonyítékok, bizonyítási indítványok előterjesztésére.

A rendelkezési elv a közigazgatási perekben olyan értelemben is sajátosan érvényesül, hogy a bíróság nincs kötve a felperes kereseti kérelméhez olyan értelemben, hogy a jogszabálysértő közigazgatási cselekményt megváltoztatja vagy hatályon kívül helyezi. ${ }^{21} \mathrm{~A}$ Kp. a bíróság reformatórius jogkörét új alapokra helyezi: nem csak törvényi felhatalmazás alapján engedi meg a jogszabálysértő közigazgatási cselekmény megváltoztatását, hanem általános döntési lehetőségként kínálja fel a Kp. 90. \-ában foglaltak betartásával.

${ }^{21}$ Kiss Daisy: Közigazgatási perek, in: Németh János - Kiss Daisy (szerk.): A polgári perrendtartás magyarázata, Budapest, CompLex Kiadó, 2010, 1320. 
A 2018. január1-je után kezdeményezett pereket illetően az eljárásjogi reform eredményét is mérlegelve azt a következtetést vonhatjuk le, hogy a jogazonosság kérdése könnyebben megítélhető a közigazgatási perben és a polgári perben hozott ítéletek összevetése szempontjából. A közigazgatási perben a bíróság a közigazgatási tevékenység jogszerűségét jogszabálysértésre hivatkozva ítéli meg, a szerződések érvénytelensége körében kezdeményezett polgári perben pedig a felperes konkrét jogállításra köteles, melyhez a bíróság kötve van. E meggondolás alapján levonhatnánk azt a következtetést, hogy amennyiben a termőfölddel kapcsolatos adásvételi szerződés kapcsán közigazgatási pert kezdeményeznek, akkor a közigazgatási perben hozott ítélet jogereje kizárja, hogy később polgári perben a felperes arra hivatkozzon, hogy az adásvételi szerződés jogszabályba ütközés miatt semmis, hiszen a jogazonosság megállapítható. A mezőgazdasági igazgatási szervnek ugyanis az Fftv. 23. S (1) bekezdésének a) pontja szerint ezt vizsgálnia kell a közigazgatási eljárás keretében, és a vizsgálat jogszerűsége vitatható a közigazgatási perben.

Ugyanakkor az anyagi jogerő megállapításához a jogazonosságon kívül a tényazonosság és a félazonosság is szükséges. A közigazgatási perben és a szerződés érvénytelenségének megállapítása iránti polgári perben a félazonosság nem állapítható meg, illetve az sem kizárt, hogy a polgári perben a felperes más tényeket is megjelöljön a keresetlevelében. Ebből az okfejtésből pedig az a végső következtetés vonható le, hogy az anyagi jogerô jogintézménye szempontjából nincs eljárásjogi akadálya a közigazgatási perben hozott ítélet után a polgári per kezdeményezésének a szerződés érvénytelenségének megállapítása iránt.

\section{A tényállás szabad megállapításának elve}

A Kp. és a Pp. párhuzamos hatályba lépése miatt számos olyan eljárásjogi rendelkezéssel találkozhatunk, mely a két törvény egymáshoz való viszonyát rendezi. Ilyen rendelkezést találhatunk a Pp. 264. \-ában is a tényállás szabad megállapításának elve kapcsán.

A tényállás szabad megállapításának elvével összefüggésben a Pp. 263. \(2) bekezdése rögzíti azt a főszabályt, mely szerint a bíróságot határozatának meghozatalában más hatóság döntése vagy a fegyelmi határozat, illetve az azokban meghatározott tényállás nem köti. E főszabály alól azonban vannak kivételek, azaz bizonyos esetekben a tényállás szabad megállapításának vannak korlátai: a Pp. 264. \ (2) bekezdése értelmében a körigazgatási ügyben eljáró biróság közigazgatási tevékenység jogszerüségének kérdésében hozott jogerös döntése az e törvény hatálya alá tartozó ügyben eljáró biróságot köti. E rendelkezés a közigazgatási bíróság jogerős ítéletében foglalt jogi minősítés tekintetében köti meg a polgári bíróság kezét: a polgári bíróság tehát nem juthat arra a következtetésre, hogy a közigazgatási perben eljáró bíróság tévesen minősítette jogszerűnek vagy jogszerűtlennek a vizsgált közigazgatási cselekményt.

Ez a relatíve kötöttség a tanulmány által felvetett probléma megválaszolása kapcsán érdekes kérdéseket vet fel. Ha ugyanis a közigazgatási perben a bíróság vizsgálta a termőfölddel kapcsolatos adásvételi szerződés jogszabályba ütközésének kérdését, és arra a következtetésre jutott, hogy az nem ütközik jogszabályba, akkor azonos tényállás mellett a polgári bíróság sem juthat más következtetésre, ellenkező 
esetben közvetett úton azt mondaná ki, hogy a közigazgatási cselekmény (a mezőgazdasági igazgatási szerv jóváhagyó záradéka) jogszabálysértő.

A Pp. 264. \ (2) bekezdésében rögzített szabály ugyanakkor továbbra sem adhat megnyugtató választ számunkra, hiszen e rendelkezés beiktatására alapvetően azért került sor, mert a Ptk. 6:548. \-a alapján kezdeményezett közigazgatási jogkörben okozott kár megtérítése iránti per megindításának eljárásjogi feltétele, hogy a közigazgatási perben a bíróság jogerôs ítélettel mondja ki a közigazgatási tevékenység jogszerűtlenségét a Pp. 24. \(3) bekezdése alapján. ${ }^{22}$ A közigazgatási jogkörben okozott kár megtérítésével kapcsolatos perekben a jogalkotó megosztotta a hatáskört a közigazgatási és polgári bíróság között, és a polgári bíróság kötve van a közigazgatási bíróság jogerős döntéséhez.

\section{Záró gondolatok}

Az eljárásjogi reformok után is elmondható, hogy a Földforgalmi törvény által lehetővé tett párhuzamos eljárások megindításának problematikája továbbra sem válaszolható meg egyértelmúen. Eljárásjogi szempontból nincs akadálya annak, hogy akár ugyanazon jogállítással a közigazgatási per jogerős lezárást követően a sérelmet szenvedett fél polgári pert kezdeményezzen a szerződés érvénytelenségének megállapítása iránt. Ugyanakkor azonos tényállás mellett a polgári bíróság nem juthat a közigazgatási bíróságtól eltérő jogi következtetésre. Az viszont előfordulhat, hogy a polgári perben - a per eltérő jellegére is figyelemmel - felmerülnek olyan új tények, melyeket a hatóság a közigazgatási eljárásban, és az azt követő közigazgatási perben a bíróság sem vizsgált, és melyek eltérő jogi minősítést eredményezhetnek.

22 Pribula László: Joghatóság, hatáskör, illetékesség, in: Nagy Adrienn - Wopera Zsuzsa (szerk.): Polgári eljárásjog I., Budapest, Wolters Kluwer Kiadó, 2017, 68. 